University of Nebraska - Lincoln

DigitalCommons@University of Nebraska - Lincoln

Publications from USDA-ARS / UNL Faculty

U.S. Department of Agriculture: Agricultural

Research Service, Lincoln, Nebraska

2011

Forage soybean yield and quality response to water use

David C. Nielsen

USDA-ARS, dcnielsen55@gmail.com

Follow this and additional works at: https://digitalcommons.unl.edu/usdaarsfacpub

Part of the Agricultural Science Commons

Nielsen, David C., "Forage soybean yield and quality response to water use" (2011). Publications from USDA-ARS / UNL Faculty. 868.

https://digitalcommons.unl.edu/usdaarsfacpub/868

This Article is brought to you for free and open access by the U.S. Department of Agriculture: Agricultural Research Service, Lincoln, Nebraska at DigitalCommons@University of Nebraska - Lincoln. It has been accepted for inclusion in Publications from USDA-ARS / UNL Faculty by an authorized administrator of DigitalCommons@University of Nebraska - Lincoln. 


\title{
Forage soybean yield and quality response to water use
}

\author{
David C. Nielsen* \\ USDA-ARS, Central Great Plains Research Station, 40335 County Road GG, Akron, CO 80720, United States
}

\section{A R T I C L E I N F O}

\section{Article history:}

Received 18 March 2011

Received in revised form 19 July 2011

Accepted 21 July 2011

\section{Keywords:}

Forage soybean

Water use

Dry matter

Forage quality

Water use efficiency

Production function

Yield prediction

\begin{abstract}
A B S T R A C T
Forages could be used to diversify reduced and no-till dryland cropping systems from the traditional wheat (Triticum aestivum L.)-fallow system in the semiarid central Great Plains. Forages present an attractive alternative to grain and seed crops because of greater water use efficiency and less susceptibility to potentially devastating yield reductions due to severe water stress during critical growth stages. However, farmers need a simple tool to evaluate forage productivity under widely varying precipitation conditions. The objectives of this study were to (1) quantify the relationship between crop water use and dry matter (DM) yield for soybean (Glycine max L. Merrill), (2) evaluate changes in forage quality that occur as harvest date is delayed, and (3) determine the range and distribution of expected DM yields in the central Great Plains based on historical precipitation records. Forage soybean was grown under a line-source gradient irrigation system to impose a range of water availability conditions at Akron, CO. Dry matter production was linearly correlated with water use resulting in a production function slope of $21.2 \mathrm{~kg} \mathrm{ha}^{-1} \mathrm{~mm}^{-1}$. The slope was much lower than previously reported for forage production functions for triticale (X Triticosecale Wittmack) and millet (Setaria italic L. Beauv.), and only slightly lower than slopes previously reported for corn (Zea mays L.) and pea (Pisum sativa L.) forage. Forage quality was relatively stable during the last four weeks of growth, with small declines in crude protein (CP) concentration. Values of $\mathrm{CP}$ concentration and relative feed value indicated that forage soybean was of sufficient quality to be used for dairy feed. A standard seed variety of maturity group VII was found to be similar (in both productivity and quality) to a variety designated as a forage type. The probability of obtaining a break-even yield of at least $4256 \mathrm{~kg} \mathrm{ha}^{-1}$ was $90 \%$ as determined from long-term precipitation records used with the production function. The average estimated DM yield was $5890 \mathrm{~kg} \mathrm{ha}^{-1}$ and ranged from 2437 to $9432 \mathrm{~kg} \mathrm{ha}^{-1}$. Regional estimates of mean forage soybean DM yield ranged from $4770 \mathrm{~kg} \mathrm{ha}^{-1}$ at Fort Morgan, CO to $6911 \mathrm{~kg} \mathrm{ha}^{-1}$ at Colby, KS. Forage soybean should be considered a viable alternative crop for dryland cropping systems in the central Great Plains.
\end{abstract}

Published by Elsevier B.V.

\section{Introduction}

Diversifying the traditional dryland winter wheat-fallow cropping system employed in the central Great Plains of the US requires information on the production potential of alternative crops that could be grown in this region. Because of the highly variable and frequently limited nature of precipitation in this region, forage production presents an attractive alternative to grain crop production. Forage production is not as highly influenced by precipitation during critical reproductive and grain-filling periods as is grain production (Nielsen et al., 1996, 2008, 2010a). Consequently, farmers may discern less risk and be more inclined to include a forage crop in their cropping systems. A recent review of cropping systems across the Great Plains region of North America (Nielsen et al., 2005) indicated that systems utilizing forages generally had greater pre-

\footnotetext{
* Tel.: +1 9703450507.

E-mail address: david.nielsen@ars.usda.gov
}

cipitation use efficiencies (based on both mass produced per unit of precipitation received and gross value of product per unit of precipitation received) than systems that did not include forages. A crop that may have potential to be grown for forage in dryland cropping systems in the central Great Plains region is soybean.

The primary use of soybean following its introduction into the US in the mid 1800s was as a forage crop (Probst and Judd, 1973). Soybean acreage for grain in the US first exceeded acreage for forage in 1941 because of growing demand for soybean oil and meal. In recent years there has been renewed interest in soybean forage production as new varieties have been bred specifically for this purpose (Devine and Hatley, 1998; Devine et al., 1998; Devine and McMurtrey, 2004).

A few studies have been reported that provide information on yield and quality of forage soybean, with yields varying widely from $1170 \mathrm{~kg} \mathrm{ha}^{-1}$ in Oklahoma (MacKown et al., 2007) to $11,700 \mathrm{~kg} \mathrm{ha}^{-1}$ in Iowa (Darmosarkoro et al., 2001) primarily due to varying water availability from location to location and from year to year. Wiederholt and Albrecht (2003) reported forage soybean quality 
Table 1

Soybean planting date, monthly precipitation, and monthly mean temperature at Akron, CO.

\begin{tabular}{|c|c|c|c|c|c|c|c|c|c|c|c|}
\hline \multirow[t]{2}{*}{ Year } & \multirow[t]{2}{*}{ Variety } & \multirow[t]{2}{*}{ Planting date } & \multicolumn{5}{|c|}{ Precipitation (mm) } & \multicolumn{4}{|c|}{ Mean temperature $(\mathrm{C})$} \\
\hline & & & June & July & August & September & Total & June & July & August & September \\
\hline 2001 & Donegal & 1 June & 34 & 68 & 57 & 46 & 205 & 20.2 & 24.7 & 22.5 & 18.1 \\
\hline 2004 & $\begin{array}{l}\text { Donegal } \\
\text { Dekalb H7242RR }\end{array}$ & $\begin{array}{l}28 \text { May } \\
4 \text { June }\end{array}$ & 64 & 43 & 68 & 40 & 215 & 18.2 & 22.0 & 20.4 & 18.6 \\
\hline 2008 & 97NYCZ33-1 & 23 May & 67 & 42 & 160 & 38 & 307 & 18.9 & 24.6 & 21.3 & 16.2 \\
\hline $1908-2010$ & & & 63 & 67 & 55 & 31 & 216 & 19.2 & 23.1 & 22.0 & 16.9 \\
\hline
\end{tabular}

produced in Wisconsin to be similar to that of alfalfa forage with a relative feed value (RFV) of 150 . However, they recommended the use of standard grain varieties rather than newer forage varieties since those forage varieties had lower forage quality because of a low percentage of pods and grain. Sheaffer et al. (2001) reached a similar conclusion for forage soybean grown in Minnesota in consequence of the forage varieties not reaching the full seed (R6, Fehr and Caviness, 1977) or beginning maturity (R7) growth stage prior to harvest. In that study the average $\mathrm{CP}$ concentration for forage varieties was $14.6 \%$, while the average CP concentration for grain varieties was $20.4 \%$. In addition, they found that both acid detergent fiber (ADF) and neutral detergent fiber (NDF) were greater for the forage varieties ( $42.4 \%$ and $50.1 \%$, respectively) than for the grain variety (30.8\% and $37.3 \%$, respectively). MacKown et al. (2007) reported a wide range of forage soybean CP concentration (12.9-22.0\%). In a study conducted with both grain and forage type soybeans in northeastern Texas, Heitholt et al. (2004) found that CP in the forage of both forage and grain varieties ranged widely from $8.7 \%$ to $17.2 \%$. They also found ADF ranging from $24.1 \%$ to $33.6 \%$, NDF ranging from $33.2 \%$ to $48.9 \%$, and RFV ranging from 120 to 196.

The response of soybean forage production to water use has not been previously reported. Data reported by Rao and Northup (2008) from a 3-year study conducted in Oklahoma can be used to define a water use/yield production function of

DM $\left(\mathrm{kg} \mathrm{ha}^{-1}\right)=9.5 \times[$ water use $(\mathrm{mm})-171]$

The data used to construct this production function consisted of only three points and had a yield range of $2024-8410 \mathrm{~kg} \mathrm{ha}^{-1}$ and a water use range of $230-772 \mathrm{~mm}$. For comparison, Nielsen et al. (2006) reported greater dry matter production function slopes (24.2-33.0 kg ha-1 $\mathrm{mm}^{-1}$ ) for corn, pea, foxtail millet, and triticale grown under dryland conditions in Colorado. The water use efficiency of forage soybean reported by Rao and Northup (2008) in Oklahoma ranged from 10.9 to $16.0 \mathrm{~kg} \mathrm{ha}^{-1} \mathrm{~mm}^{-1}$.

In order to assess and quantify the risk involved in producing a dryland forage crop in the highly variable available water conditions of the semiarid Great Plains, this study had the following objectives: (1) quantify the relationship between crop water use and DM yield for forage soybean, (2) evaluate changes in forage quality that occur as harvest date is delayed, and (3) determine the range and distribution of expected DM yields in the central Great Plains based on historical precipitation records. The results would allow both agricultural producers and lenders to assess the risk level that might be incurred in moving from conventional wheatfallow production systems to more intensively cropped systems employing forages.

\section{Materials and methods}

This study was conducted during 2001, 2004, and 2008 at the USDA Central Great Plains Research Station, $6.4 \mathrm{~km}$ east of Akron, $\mathrm{CO}\left(40^{\circ} 09^{\prime} \mathrm{N}, 103^{\circ} 09^{\prime} \mathrm{W}, 1384 \mathrm{~m}\right)$. The soil type was a Weld silt loam (fine, smectitic, mesic Aridic Argiustoll). The forage soybean 'Donegal' (Devine and Hatley, 1998) was planted in 2001 and 2004.
'Donegal' is a maturity group (MG) V variety. In 2004 a traditional seed variety adapted for southern latitudes ('Dekalb H7242RR', MG VII) was also grown for comparison with 'Donegal'. In 2008 seed of the more early maturing variety '97NYCZ33-1' (MG III) was planted. Planting occurred between 23 May and 4 June (Table 1) at seeding rates varying between 494,000 and 580,500 seeds ha ${ }^{-1}$. Seeds were inoculated with Bradyrhizobium japonicum prior to planting.

Plots were established under a line-source gradient irrigation system diagrammed and described in Nielsen (2004) in which water application amount declined linearly with distance from the irrigation line. With this system four replications of four nonrandomized water treatments were created, designated in this study as Gradient 1 (rainfed), Gradient 2, Gradient 3, and Gradient 4 (high water treatment). The average amounts of irrigation water applied for each treatment are given in Table 2. Irrigations were generally applied in the evening when wind speeds were low to minimize differences in water application due to shifts in the spray patterns. Individual plot size was $6.1 \mathrm{~m}$ by $12.2 \mathrm{~m}$. Row spacing was $38 \mathrm{~cm}$ and row direction was north-south.

Water use (also known as evapotranspiration or ET) was calculated for each plot by the water balance method using soil water measurements and assuming runoff and deep percolation were negligible (a reasonable assumption as plot area slope was less than $0.5 \%$ and amounts of growing season precipitation were generally small). Irrigation amounts were recorded with catch gauges located in the center of each plot. Soil water measurements were made at planting and harvest in the center of each of the plots using a neutron probe. Measurement depths were 15, 45, 75, 105, 135, and $165 \mathrm{~cm}$ below the soil surface. The neutron probe was calibrated against gravimetric soil water samples taken in the plot area. Gravimetric soil water was converted to volumetric water by multiplying by the soil bulk density for each depth. Daily precipitation was recorded in the plot area.

In 2001 and 2004 DM yields were sampled just prior to frost by cutting plants at the soil surface from a $3.05 \mathrm{~m}$ length of the two rows surrounding the soil water measurement site in each plot. The growth stage was R6 (full seed) for 'Donegal' and R1 (beginning flower) for the later-maturing 'Dekalb H7242RR'. In 2008 the effect of harvest date on DM yield and quality was investigated by taking six sequential samples with growth stages ranging from R1 (beginning flower on 13 August) to R7 (beginning maturity on 30 September). The harvest dates and growth stages are given in Table 2. The final harvest in 2008 was done as described above for 2001 and 2004, but the preceding harvests consisted of $1 \mathrm{~m}$ of one row in areas adjacent to the soil water sampling site but still the same distance from the irrigation line as the soil water sampling site in the center of the plot.

Dry matter samples were weighed, dried at $60^{\circ} \mathrm{C}$ to a constant weight, and weighed again. Samples were ground to pass a $1-\mathrm{mm}$ screen and sent to a commercial laboratory (Olsen's Agricultural Laboratory, McCook, NE) for forage analysis. Crude protein concentration was determined by N combustion (Cuniff, 1995); NDF and ADF were determined by refluxing (kettle method, Undersander et al., 1993); RFV was calculated according to the relationship given by Kuehn et al. (1999). While the RFV index was developed to 
Table 2

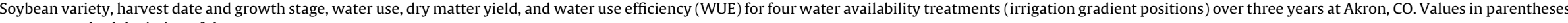
are one standard deviation of the mean.

\begin{tabular}{|c|c|c|c|c|c|c|c|c|c|}
\hline Year & Variety & Harvest date & $\begin{array}{l}\text { Harvest growth } \\
\text { stage }\end{array}$ & Harvest DAP & $\begin{array}{l}\text { Irrigation gradient } \\
\text { position }\end{array}$ & $\begin{array}{l}\text { Irrigation } \\
\text { amount (mm) }\end{array}$ & Water use $(\mathrm{mm})$ & Yield $\left(\mathrm{kg} \mathrm{ha}^{-1}\right)$ & $\begin{array}{l}\text { WUE } \\
\left(\mathrm{kg} \mathrm{ha}^{-1} \mathrm{~mm}^{-1}\right)\end{array}$ \\
\hline \multirow[t]{4}{*}{2001} & Donegal & 26 September & R6 & 117 & 1 & 0 & $362(14)$ & $6274(364)$ & $17.3(0.9)$ \\
\hline & (MGV) & 27 September & R6 & 118 & 2 & 97 & $461(26)$ & 7992 (1093) & $17.3(2.3)$ \\
\hline & & 27 September & R6 & 118 & 3 & 161 & $514(26)$ & $8156(741)$ & $15.9(1.5)$ \\
\hline & & 2 October & R6 & 123 & 4 & 253 & $614(26)$ & $10,139(88)$ & $16.5(0.4)$ \\
\hline \multirow[t]{4}{*}{2004} & Donegal & 30 September & Early R6 & 125 & 1 & 0 & $283(17)$ & $2720(458)$ & $9.7(1.9)$ \\
\hline & (MGV) & 30 September & Early R6 & 125 & 2 & 33 & $352(35)$ & $4547(282)$ & $13.1(2.0)$ \\
\hline & & 30 September & Early R6 & 125 & 3 & 76 & $373(9)$ & $5324(2087)$ & $14.3(5.8)$ \\
\hline & & 30 September & Early R6 & 125 & 4 & 120 & $414(30)$ & $8714(793)$ & $21.1(2.2)$ \\
\hline \multirow[t]{4}{*}{2004} & Dekalb H7242RR (MG VII) & 30 September & R1 & 118 & 1 & 0 & $255(52)$ & 3935 (1205) & $15.2(2.3)$ \\
\hline & & 30 September & R1 & 118 & 2 & 33 & $263(54)$ & $4885(1884)$ & $18.0(3.7)$ \\
\hline & & 30 September & R1 & 118 & 3 & 76 & $358(20)$ & 6804 (939) & $19.1(2.9)$ \\
\hline & & 30 September & R1 & 118 & 4 & 120 & $378(22)$ & $6376(1556)$ & $16.8(3.3)$ \\
\hline \multirow[t]{24}{*}{2008} & 97NYCZ33 (MG III) & 13 August & R1 & 82 & 1 & 0 & $208(33)$ & $2630(269)$ & $12.9(2.3)$ \\
\hline & & 13 August & R1 & 82 & 2 & 55 & $266(25)$ & 3265 (525) & $12.4(2.5)$ \\
\hline & & 13 August & R1 & 82 & 3 & 140 & $324(22)$ & 3960 (336) & $12.3(1.4)$ \\
\hline & & 13 August & R1 & 82 & 4 & 212 & $352(48)$ & $4760(1071)$ & $13.9(4.3)$ \\
\hline & & 27 August & R3 & 96 & 1 & 0 & $284(43)$ & $4957(586)$ & $17.7(3.0)$ \\
\hline & & 27 August & R3 & 96 & 2 & 55 & $336(41)$ & $4852(446)$ & $14.7(3.1)$ \\
\hline & & 27 August & R3 & 96 & 3 & 140 & $392(16)$ & $6924(976)$ & $17.7(3.1)$ \\
\hline & & 27 August & R3 & 96 & 4 & 212 & $420(83)$ & 7507 (674) & $18.5(4.5)$ \\
\hline & & 3 September & R4 & 103 & 1 & 0 & $325(34)$ & $6543(464)$ & $20.4(3.4)$ \\
\hline & & 3 September & R4 & 103 & 2 & 55 & $382(31)$ & $6635(1202)$ & $17.6(4.2)$ \\
\hline & & 3 September & R4 & 103 & 3 & 140 & 444 (18) & 8688 (1678) & $19.5(3.0)$ \\
\hline & & 3 September & R4 & 103 & 4 & 212 & $473(68)$ & 8740 (1409) & $18.8(4.7)$ \\
\hline & & 10 September & R5 & 110 & 1 & 0 & $351(33)$ & 8412 (2012) & $24.4(7.2)$ \\
\hline & & 10 September & R5 & 110 & 2 & 75 & $416(31)$ & $6497(487)$ & $15.7(1.6)$ \\
\hline & & 10 September & R5 & 110 & 3 & 161 & $471(20)$ & $8649(970)$ & $18.3(1.7)$ \\
\hline & & 10 September & R5 & 110 & 4 & 244 & 496 (64) & $8609(401)$ & $17.5(2.0)$ \\
\hline & & 17 September & R6 & 117 & 1 & 0 & $375(31)$ & $7967(920)$ & $21.4(3.1)$ \\
\hline & & 17 September & R6 & 117 & 2 & 75 & $449(28)$ & $8668(945)$ & $19.4(2.1)$ \\
\hline & & 17 September & R6 & 117 & 3 & 161 & $505(25)$ & $10,498(1371)$ & $20.8(2.4)$ \\
\hline & & 17 September & R6 & 117 & 4 & 244 & $532(67)$ & $9953(1072)$ & $18.7(0.6)$ \\
\hline & & 30 September & R7 & 130 & 1 & 0 & $413(30)$ & $6464(795)$ & $15.8(2.8)$ \\
\hline & & 30 September & R7 & 130 & 2 & 75 & $494(25)$ & 7212 (1089) & $14.7(2.5)$ \\
\hline & & 30 September & R7 & 130 & 3 & 161 & $567(36)$ & 8080 (1030) & $14.2(1.0)$ \\
\hline & & 30 September & R7 & 130 & 4 & 244 & $603(48)$ & 8646 (1289) & $14.5(3.1)$ \\
\hline
\end{tabular}


categorize alfalfa hay for marketing purposes, it is useful for providing some understanding of changes in soybean forage quality with growth stage and time of harvest considering that the NDF/ADF ratio for forage soybean is similar to alfalfa (1.2-1.6).

The water use/yield production function was determined by linear regression. As the water treatments were not randomized, standard deviations of the treatment means of the four replicate measurements were calculated to aid in assessing differences due to water treatment. Statistical analysis was performed using Statistix 9 software (Analytical Software, 2008).

\section{Results}

\subsection{Weather}

Total growing season precipitation was near average in 2001 and 2004 , but $42 \%$ above average in 2008 (Table 1 ). Dry conditions were encountered in 2001 with June precipitation $54 \%$ of average. July precipitation in 2004 and 2008 was below average. August of 2008 was very wet with nearly three times greater than average precipitation resulting in no irrigation between 1 August and 3 September. Warmer than average conditions were observed through the entire growing season in 2001, while in 2004 cooler than average conditions occurred until September. July of 2008 was warmer than average while the rest of the 2008 growing season was slightly cooler than average.

\subsection{Water use}

Water use in 2001 ranged from $362 \mathrm{~mm}$ for the rainfed treatment with no irrigation (Table 2) to $614 \mathrm{~mm}$ for the Gradient 4 position which received $253 \mathrm{~mm}$ irrigation water. Water use was less for all water treatments in 2004 due to the lower application of irrigation which ranged from $0 \mathrm{~mm}$ for the rainfed treatment to $120 \mathrm{~mm}$ for the Gradient 4 position. Water application in 2008 ranged from $0 \mathrm{~mm}$ for the rainfed treatment to $244 \mathrm{~mm}$ for the Gradient 4 position resulting in water use through the R6 growth stage ranging from $375 \mathrm{~mm}$ to $532 \mathrm{~mm}$. For the rainfed treatment in 2001, $52 \%$ of the water use came from stored soil water extraction and $48 \%$ from growing season precipitation. In 2004 the rainfed treatment was comprised of $26 \%$ stored soil water extraction and $74 \%$ growing season precipitation. In 2008 (the wettest year) the water use to the R6 growth stage was $20 \%$ from stored soil water extraction and $80 \%$ from growing season precipitation. Averaged across the three years of the study, water use at the Gradient 4 position was comprised of about $15 \%$ stored soil water extraction, $45 \%$ growing season precipitation, and $40 \%$ irrigation.

\subsection{Dry matter yield and water use/yield production function}

Soybean forage DM ranged from $2630 \mathrm{~kg} \mathrm{ha}^{-1}$ for the first cutting of the low water treatment in 2008 to $10,498 \mathrm{~kg} \mathrm{ha}^{-1}$ for the R6 cutting of the Gradient 3 water treatment in 2008 (Table 2). Dry matter increased linearly with increasing water use (Fig. 1). All of the data sets appear to fit one regression line except for the data collected during the last sampling period (September 30) in 2008. We presume that there was probably loss of biomass from leaf senescence occurring by this date when the plants were at the $\mathrm{R} 7$ growth stage. The regression line fit to all of the data excluding this last sampling period in 2008 produced a water use/yield production function of

$\mathrm{DM}\left[\mathrm{kg} \mathrm{ha}^{-1}\right]=21.20 \times($ water use $[\mathrm{mm}]-72.0)$

Variations in water use explained $79 \%$ of the variation in biomass production.

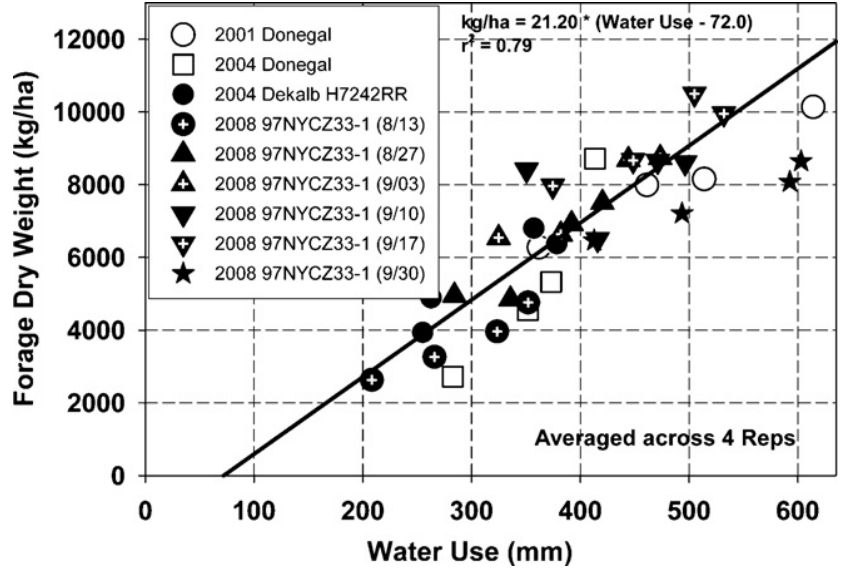

Fig. 1. Forage soybean dry weight vs. water use at Akron, CO. Data from 30 September 2008 (stars) not included in regression.

\subsection{Water use efficiency}

Water use efficiency (WUE) ranged from $9.7 \mathrm{~kg} \mathrm{ha}^{-1} \mathrm{~mm}^{-1}$ for 'Donegal' grown at the low water treatment in 2004 to $24.4 \mathrm{~kg} \mathrm{ha}^{-1} \mathrm{~mm}^{-1}$ for '97NYCZ33-1' harvested at growth stage R5 from the low water treatment in 2008 (Table 2). There was no consistent trend regarding irrigation amount on WUE. Water use efficiency for the Gradient 1 treatment in 2008 generally increased from R1 to R4 (12.9-24.4 $\left.\mathrm{kg} \mathrm{ha}^{-1} \mathrm{~mm}^{-1}\right)$ and then declined to the end of the growing season. For the other three water treatments WUE increased through R3 and then remained fairly constant (about $18-19 \mathrm{~kg} \mathrm{ha}^{-1} \mathrm{~mm}^{-1}$ ) until R7 when WUE dropped to about $14.5 \mathrm{~kg} \mathrm{ha}^{-1} \mathrm{~mm}^{-1}$ when DM declined but water use continued to increase.

\subsection{Forage quality}

Forage quality showed some variation from year to year and with time and stage of harvest. Crude protein percentage (Fig. 2) was lowest for 'Donegal' in 2001 (10.7-15.3\%) with the highest CP found for the highest irrigation treatment. Crude protein percentage for the 2004 'Donegal' crop was greater (14.4-17.0\%), but in this year the highest water treatment had the lowest CP. Surprisingly, the 2004 'Dekalb' crop was not lower in CP even though it had not yet formed seed (growth stage R1 compared with R6 for 'Donegal').

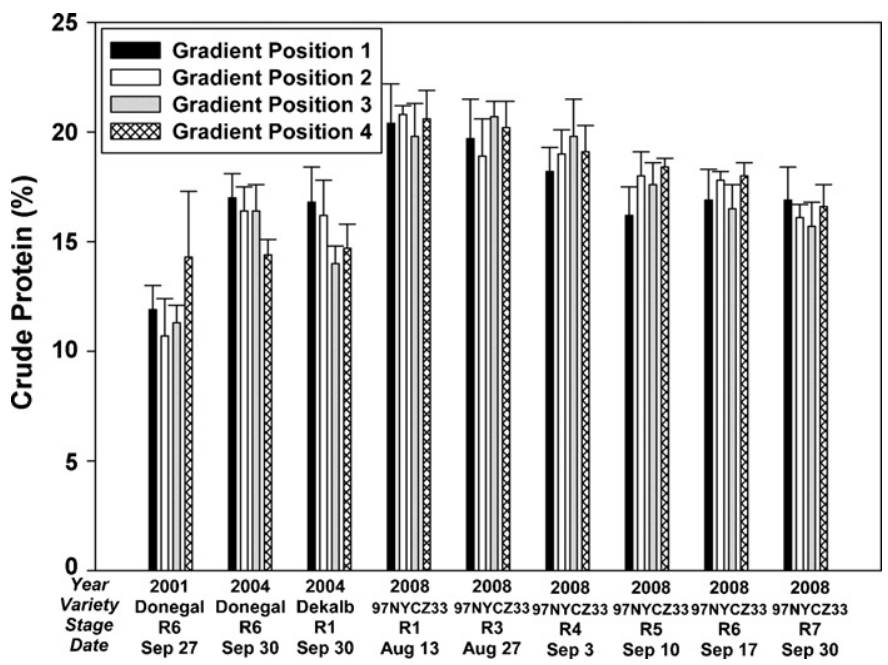

Fig. 2. Crude protein concentration of forage soybean at Akron, $\mathrm{CO}$ (expressed on a $100 \%$ dry matter basis). Error bar indicates one standard deviation above the mean. 


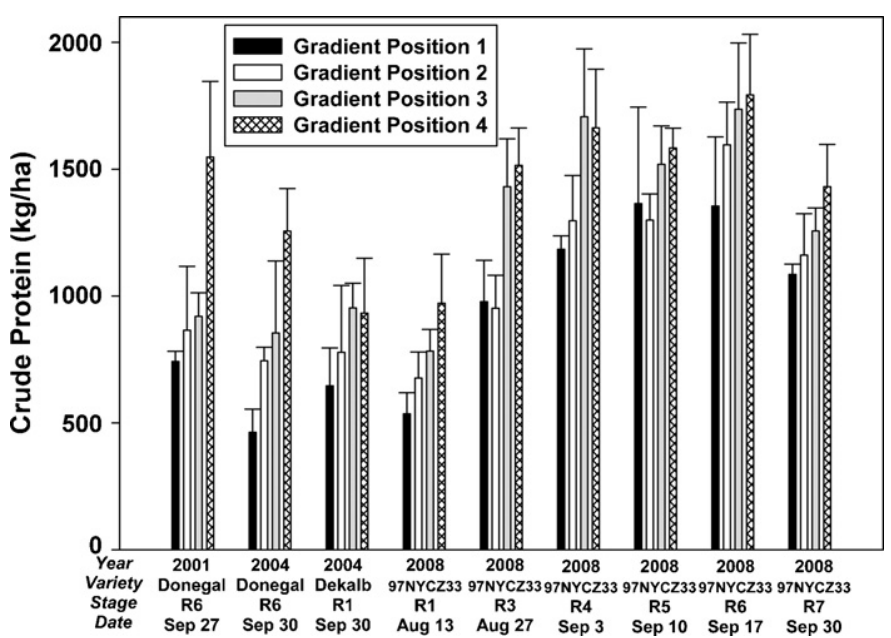

Fig. 3. Crude protein mass of forage soybean at Akron, CO. Error bar indicates one standard deviation above the mean.

Crude protein concentration was higher at all six sampling dates for the '97NYCZ33-1' crop grown in 2008 compared with the crops grown in 2001 and 2004. There was a gradual decline in CP with later sampling dates (declining from about 20.4 to $16.3 \%$ ) and no consistent effect of water treatment on $\mathrm{CP}$.

Actual CP mass ranged from $463 \mathrm{~kg} \mathrm{ha}^{-1}$ for the 2004 'Donegal' crop under dryland conditions (Gradient Position 1) to $1792 \mathrm{~kg} \mathrm{ha}^{-1}$ for the 2008 '97NYCZ33-1' crop grown at Gradient Position 4 and harvested at R6 on 17 September (Fig. 3). Crude protein mass tended to increase with increasing irrigation, primarily due to increasing DM accumulation. The data collected in 2008 indicated harvesting at $\mathrm{R} 6$ would maximize $\mathrm{CP}$ mass.

Acid detergent fiber (Fig. 4) was highest (30.1-32.9\%) for the 2001 'Donegal' crop and showed a tendency to increase with increasing irrigation. That tendency for increased ADF with increasing irrigation was seen in 2004 and 2008 as well. Acid detergent fiber was lower in 2004 than in 2001 and was not different between 'Donegal' and 'Dekalb' (mean values of 25.2 and 24.2, respectively) even though the two varieties were at very different growth stages. Acid detergent fiber for the 2008 ' 97 NYCZ33-1' crop increased with plant development up to growth stage $\mathrm{R} 4$ and then remained fairly constant (26-27\% for the Gradient 1 treatment and $30-32 \%$ for the Gradient 4 treatment) through stage R7.

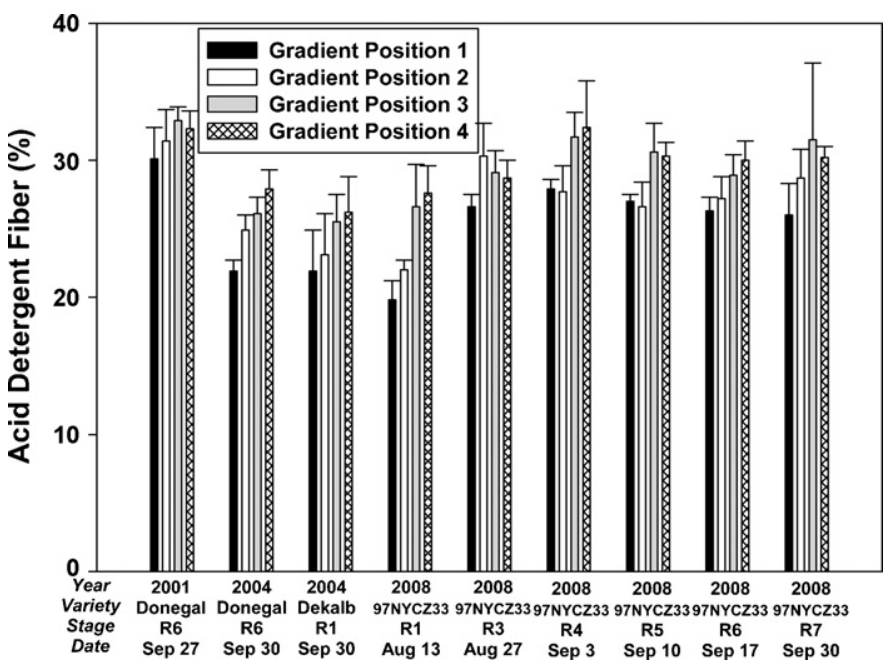

Fig. 4. Acid detergent fiber concentration of forage soybean at Akron, $\mathrm{CO}$ (expressed on a $100 \%$ dry matter basis). Error bar indicates one standard deviation above the mean.

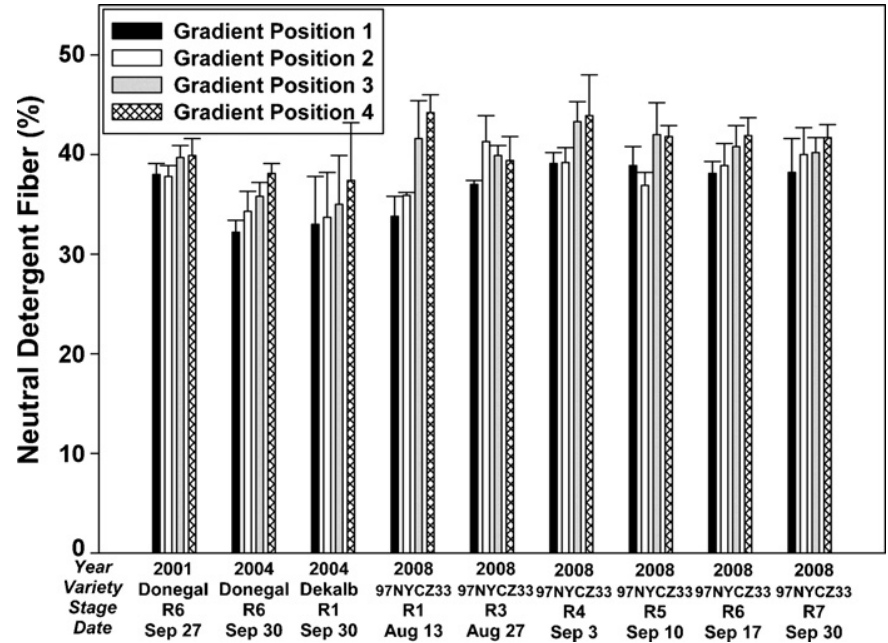

Fig. 5. Neutral detergent fiber concentration of forage soybean at Akron, CO (expressed on a $100 \%$ dry matter basis). Error bar indicates one standard deviation above the mean.

Neutral detergent fiber (Fig. 5) exhibited the same tendency as ADF to increase with increasing irrigation. As with ADF, NDF was not different between the 2004 'Donegal' and 'Dekalb' crops, but both 2004 crops exhibited somewhat lower NDF than the 2001 'Donegal' crop. Changes in NDF with growth stage in 2008 where not consistent across irrigation treatments. At the Gradient 1 position (rainfed) NDF increased up to R4 and then remained nearly constant at about 38-39\%. At the other higher levels of water availability there was no clear change in NDF.

Relative feed value (Fig. 6) varied somewhat from year to year with mean values falling in the range of 136-208. Increasing water availability generally resulted in trends for lower RFV. There was no difference in RFV between the two varieties tested in 2004 and no consistent change in RFV with harvest date in 2008.

\section{Discussion}

\subsection{Water use/yield production function}

The production function regression slope of $21.2 \mathrm{~kg} \mathrm{ha}^{-1} \mathrm{~mm}^{-1}$ was much greater than the $9.5 \mathrm{~kg} \mathrm{ha}^{-1} \mathrm{~mm}^{-1}$ defined earlier from the three data points reported by Rao and Northup (2008) in Okla-

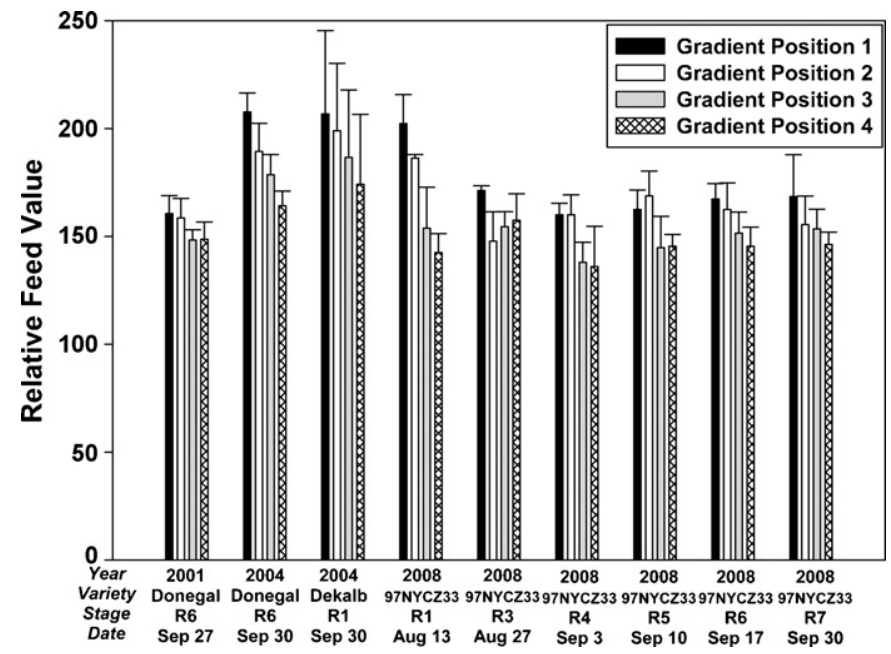

Fig. 6. Relative feed value index for forage soybean at Akron, CO. Error bar indicates one standard deviation above the mean. 


\section{Gradient Position 1 Gradient Position 2 Gradient Position 3 Gradient Position 4} (Rainfed)

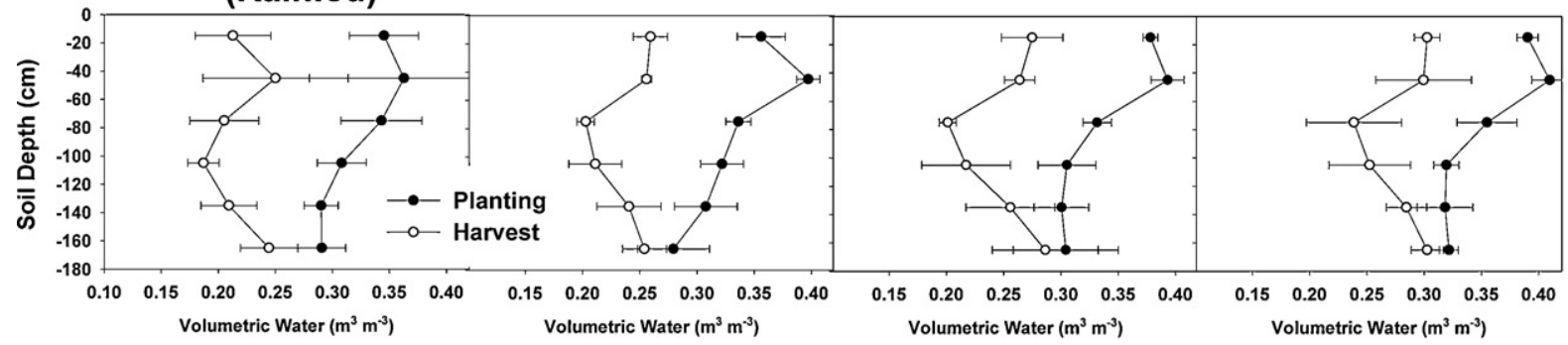

Donegal

2001

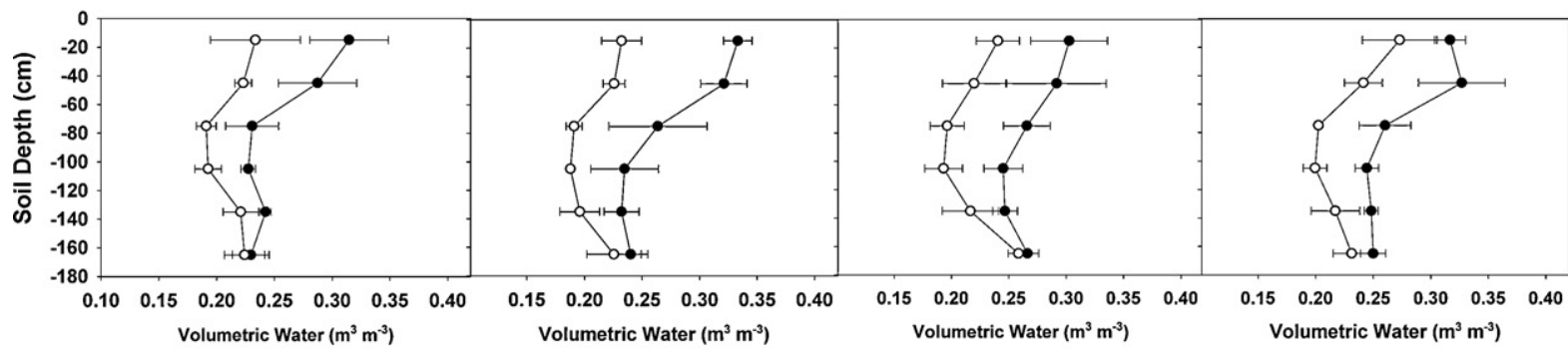

\section{Donegal}

2004

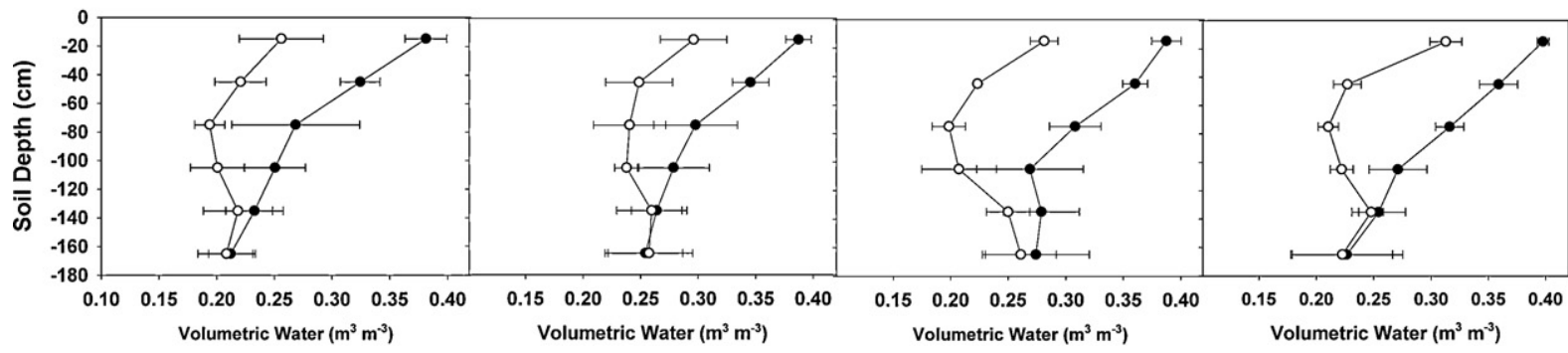

Dekalb H7242RR

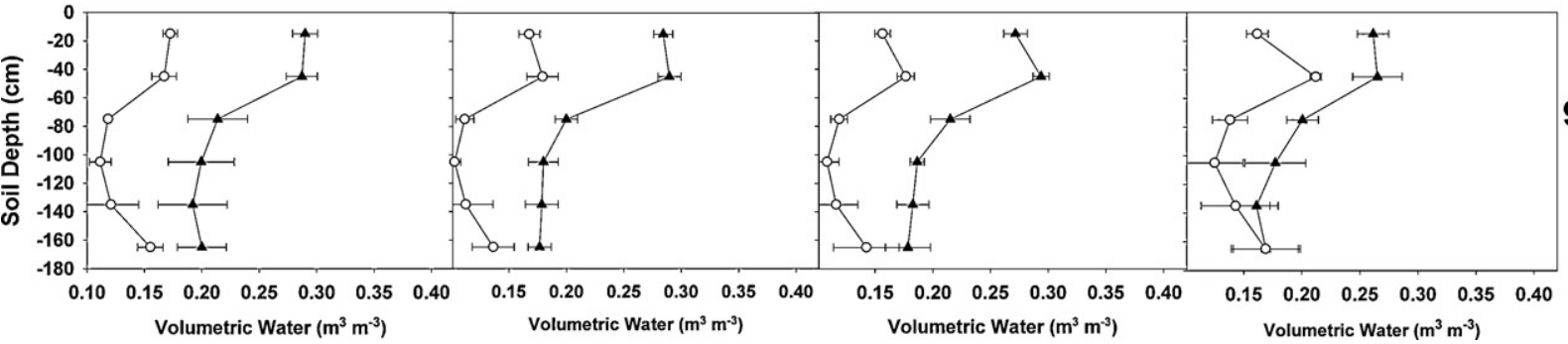

97NYCZ33-1

2008

Fig. 7. Volumetric soil water profiles at planting and final harvest of forage soybean grown at Akron, CO. Error bars indicate one standard deviation about the mean.

homa. The low slope of this relationship constructed from their data is due to the low WUE they reported for one year of their threeyear study (data point $8410 \mathrm{~kg} \mathrm{ha}^{-1}$ at $772 \mathrm{~mm}$ ). The two other data points ( $3034 \mathrm{~kg} \mathrm{ha}^{-1}$ at $230 \mathrm{~mm}$ and $7271 \mathrm{~kg} \mathrm{ha}^{-1}$ at $454 \mathrm{~mm}$ ) fall nearly on the regression production function defined in the current study (Fig. 1). The production function slope for soybean biomass found in the current study was much less than Nielsen et al. (2006) reported for winter triticale $\left(33.0 \mathrm{~kg} \mathrm{ha}^{-1} \mathrm{~mm}^{-1}\right)$ and for foxtail millet $\left(29.3 \mathrm{~kg} \mathrm{ha}^{-1} \mathrm{~mm}^{-1}\right)$. The lower production function slope for soybean biomass compared with these two crops is to be expected considering that the fraction of biomass comprised of protein and oil is greater for soybean than for triticale and millet. The photosynthetic costs of producing protein and oil are greater than for producing starch, as indicated by differences in water use efficiency found between starchy grain crops, seed legumes, and oilseed crops (Nielsen et al., 2005). The current production function slope of $21.2 \mathrm{~kg} \mathrm{ha}^{-1} \mathrm{~mm}^{-1}$ for forage soybean was somewhat less than that reported by Nielsen et al. (2006) for corn biomass ( $24.2 \mathrm{~kg} \mathrm{ha}^{-1} \mathrm{~mm}^{-1}$ ) and those that they generated from other previously reported studies with corn ranging from 23.0 to $26.2 \mathrm{~kg} \mathrm{ha}^{-1} \mathrm{~mm}^{-1}$ from Italy, Texas, and Colorado. It was also less than the slope of the production function reported by Nielsen et al. (2010b) for pea forage $\left(24.8 \mathrm{~kg} \mathrm{ha}^{-1} \mathrm{~mm}^{-1}\right)$.

\subsection{Water use efficiency}

Water use efficiency of forage soybean in Oklahoma was reported to range from 10.9 to $16.0 \mathrm{~kg} \mathrm{ha}^{-1} \mathrm{~mm}^{-1}$ (Rao and Northup, 2008). In another study from Oklahoma, Rao and Northup (2009) found that forage WUE of cowpea [Vigna unguiculata (L.) Walp], mung bean [Vigna radiate (L.) Wilcz.], guar [Cyamopsis tetragonobloba (L.) Taub.], pigeon pea [Caljanus Cajan (L.) Millsp.], and soybean were not different from one another, and averaged $19.6 \mathrm{~kg} \mathrm{ha}^{-1} \mathrm{~mm}^{-1}$, very similar to the values reported for most of the R6 samples collected in the current study (Table 2). However, they reported WUE for these five forage crops to range widely from year to year $\left(12.9-26.3 \mathrm{~kg} \mathrm{ha}^{-1} \mathrm{~mm}^{-1}\right)$ over the four years of the study, depending on growing season precipitation timing and amount. The current study also found a wide year-year variation in WUE, with means across water treatments ranging from $14.6 \mathrm{~kg} \mathrm{ha}^{-1} \mathrm{~mm}^{-1}$ for 'Donegal' in 2004 to $20.1 \mathrm{~kg} \mathrm{ha}^{-1} \mathrm{~mm}^{-1}$ for ' 97 NYCZ33-1' at R6 in 2008. 


\subsection{Forage quality}

With the exception of the 'Donegal' 2001 data, most of the $\mathrm{CP}$ values recorded in the current study were in the same range or slightly higher than the values Seiter et al. (2004) reported (13.9-17.9\%) for forage soybean grown in New Hampshire. They also found that CP increased with growth stage from R3 to R5.5, which was not a result of the current study. Sheaffer et al. (2001) found $\mathrm{CP}$ ranging from 12.5 to $16.2 \%$ for three forage soybean varieties grown in Minnesota. These $\mathrm{CP}$ concentrations were lower than the 19.0-21.8\% CP found for the standard grain variety grown in their study. They suggested that forage soybean varieties needed to be used that would reach R6 by harvest such that CP levels would be high following the formation of seed (Hintz et al., 1992). Our 2004 results did not confirm this recommendation, as both the 'Donegal' harvested at R6 and the 'Dekalb' harvested at R1 had similar CP concentrations.

The ADF values found in this study were considerably lower than the $40-42 \%$ value reported by Sheaffer et al. (2001) for forage soybean varieties grown in Wisconsin. The values of ADF reported by Seiter et al. (2004) ranged from 30.2 to $37.8 \%$ for forage soybean at R5.5. They also reported ADF to consistently increase from about $30 \%$ to about $37 \%$ as growth stage increased from R3 to R5.5.

At the most likely harvest stage of R6, NDF ranged from 38 to $42 \%$, considerably lower than the $\sim 50 \%$ value reported by Sheaffer et al. (2001) for forage soybean varieties grown in Wisconsin, and also lower than most of the values reported by Seiter et al. (2004) which ranged from 42 to $49 \%$ at R5.5. Seiter et al. (2004) also reported NDF to consistently increase from about $40 \%$ to about $49 \%$ as growth stage increased from R3 to R5.5. The current study did not find consistent changes in NDF with growth stage.

Heitholt et al. (2004) found that a forage soybean variety grown in Dallas, TX had RFV ranging from 120 to 163 over two years. They reported that RFV changed more between years than it did with growth stage within a given year, similar to what was found in the current study, where RFV averaged over water treatments ranged from 154 in 2001 to 192 in 2004 and the range of RFV due growth stage in 2008 was from 149 at R4 to 171 at R1. Wiederholt and Albrecht (2003) stated that soybean forage quality was similar to alfalfa forage with RFV of 150 . Relative feed value in the current study was mostly greater than reported by both Heitholt et al. (2004) and Wiederholt and Albrecht (2003).

Heitholt et al. (2004) suggested that suitable hay quality for lactating dairy cattle would have CP greater than $14 \%$ and RFV greater than 150. By this standard the soybean forage produced in 2001 would not be acceptable because $\mathrm{CP}$ was too low, but all other forage samples collected in this study would have acceptable levels of $\mathrm{CP}$ and RFV very near to or exceeding 150 . Both varieties grown in 2004 exceeded the $\mathrm{RFV}=150$ threshold for acceptable forage quality. Additionally, total digestible nutrients (TDN) for the forage soybean grown in this study ranged from $64.8 \%$ to $77.5 \%$ (data not shown), greater than the $60 \%$ TDN requirement noted by Poore (2011) for lactating cows.

\subsection{DM production estimates}

The production function defined in this study can be used with the historical precipitation record to estimate the distribution of expected DM production if used with some estimate of soil water use by forage soybean. Volumetric water content profiles (Fig. 7) taken at planting and harvest indicated significant extraction of soil water in the $0-135 \mathrm{~cm}$ soil layer in most years and water availability conditions. More soil water was extracted in 2001 (161 mm averaged over all four water treatments) than in $2004(101 \mathrm{~mm}$ averaged over water treatments and varieties) and $2008(137 \mathrm{~mm}$

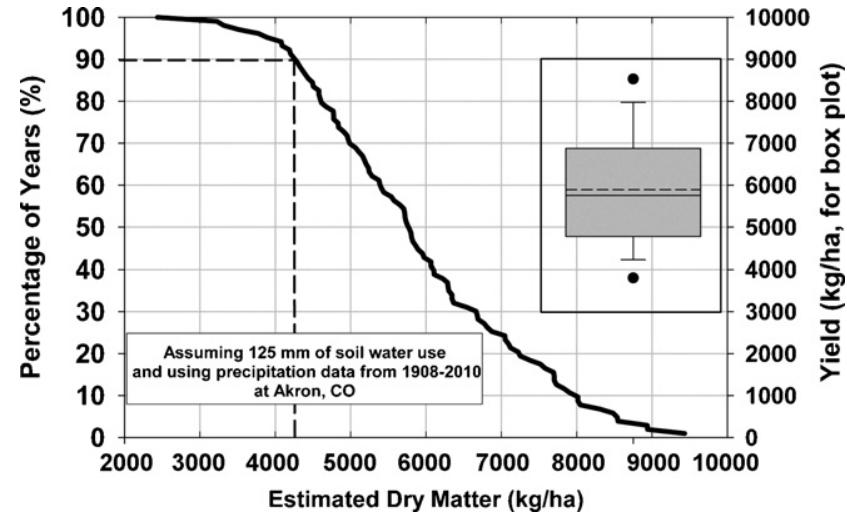

Fig. 8. Probability distribution of predicted forage soybean dry matter yields based on 103 years of precipitation data at Akron, CO. Inset box plot indicates the mean (interior dashed line), median (interior solid line), 5\% (lower dot), 10\% (lower whisker), 25\% (bottom of box), 75\% (top of box), 90\% (upper whisker), and 95\% (upper dot) yields

averaged over water treatments). The average soil water extraction over all water treatments, varieties, and years was $125 \mathrm{~mm}$.

This estimate of soil water use was added to the growing season (28 May to 23 September) precipitation record from 1908 to 2010 at Akron, $\mathrm{CO}$ to provide a range and distribution of water use values to use with the production function shown in Fig. 1. The 103 calculated water use values ranged from 187 to $516 \mathrm{~mm}$ and all but one of the values fell within the range of values used to establish the production function.

Estimated soybean DM production ranged from 2437 to $9432 \mathrm{~kg} \mathrm{ha}^{-1}$ (mean $5890 \mathrm{~kg} \mathrm{ha}^{-1}$ see Fig. 8, inset). The 4-year average forage soybean yield reported by Rao and Northup (2009) in Oklahoma was $5579 \mathrm{~kg} \mathrm{ha}^{-1}$ (range $2746-10,011 \mathrm{~kg} \mathrm{ha}^{-1}$ ) with an average growing season precipitation of $324 \mathrm{~mm}(100 \mathrm{~mm}$ more than the 103-year average precipitation at Akron), but grown immediately following a winter wheat crop in a double cropping situation. Fifty percent of the estimated DM values fell between 4800 (25th percentile) and $6850 \mathrm{~kg} \mathrm{ha}^{-1}$ (75th percentile). Dry matter production of at least $4256 \mathrm{~kg} \mathrm{ha}^{-1}$ (the forage yield threshold identified by Nielsen et al., 2010b as a break-even yield for forages) would be expected to occur $90 \%$ of the time (Fig. 8 ).

The slope and intercept of the relationship between water use and yield (Fig. 1) may shift somewhat with changes in latitude and longitude due primarily to changes in vapor pressure deficit, temperature, and evaporation (Tanner and Sinclair, 1983). As such, the production function defined in the current study should be validated at other locations. Nevertheless, the climate of the westcentral Great Plains is sufficiently uniform that the production function can probably be applied to get an initial idea regarding the productivity potential of forage soybean in other areas of a limited region varying primarily in precipitation due to the rain shadow effect of the Rocky Mountains. Annual precipitation here increases from west to east at a rate of about $63 \mathrm{~mm}$ every $100 \mathrm{~km}$ (Martin, 2007), with the gradient increasing as distance to the mountains on the west side of the region decreases. We applied the production function to seven additional locations within $220 \mathrm{~km}$ of Akron by using the long-term average precipitation for June, July, August, and September along with the measured mean soil water extraction of $125 \mathrm{~mm}$ to generate expected mean forage soybean DM yields for the region (Fig. 9). Predicted mean yield ranged from $4770 \mathrm{~kg} \mathrm{ha}^{-1}$ at Fort Morgan, CO to $6911 \mathrm{~kg} \mathrm{ha}^{-1}$ at Colby, KS. The mean yields at all of the locations were greater than the $4256 \mathrm{~kg} \mathrm{ha}^{-1}$ break-even yield for forages specified by Nielsen et al. (2010b).

Nielsen and Vigil (2010) measured a 10-year average soil water increase at Akron, $\mathrm{CO}$ of $38 \mathrm{~mm}$ over the period of 1 October to 30 


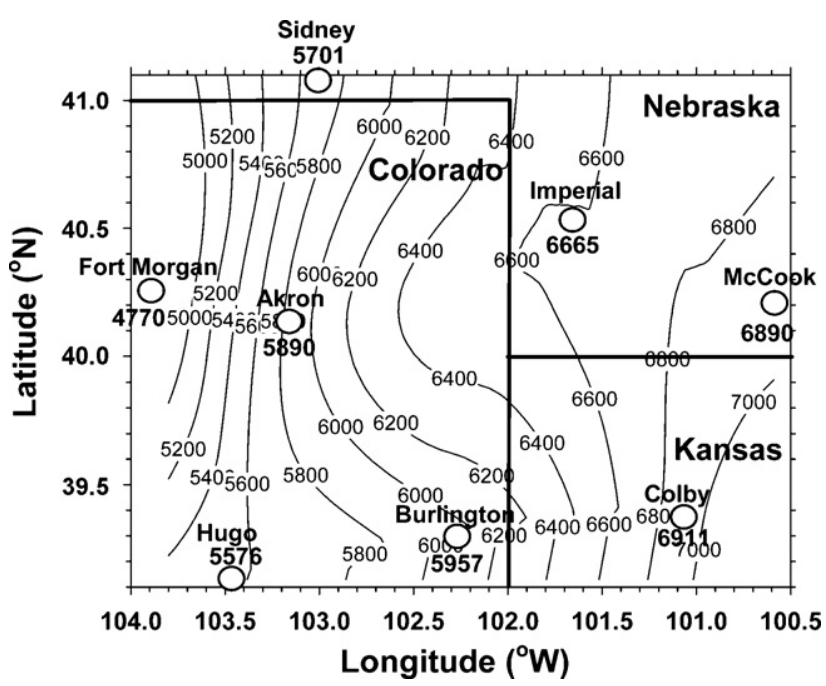

Fig. 9. Estimated mean forage soybean dry matter yields $\left(\mathrm{kg} \mathrm{ha}^{-1}\right)$ across the westcentral Great Plains.

May in a conventionally tilled winter wheat-fallow system. Because of the limited amounts of crop residue on the soil surface during the fallow period of this system and the lack of tillage occurring during this period, their data provide a reasonable estimate of the amount of soil water recharge that might be expected on fields where soybean forage has been removed. As stated earlier, the average forage soybean soil water extraction over all years and treatments was $125 \mathrm{~mm}$. Consequently, a fallow period would likely be needed for additional recharge of the stored soil water extracted by the forage soybean. A potential cropping system for this region might be winter wheat-forage soybean-fallow, allowing for production of two crops in three years.

\section{Conclusions}

Soybean DM forage production was found to be linearly related to crop water use, increasing at a rate of $21.2 \mathrm{~kg} \mathrm{ha}^{-1}$ per $\mathrm{mm}$ of water used. The production function defined by this linear relationship appears to be valid for both seed and forage varieties of varying maturity group. Forage soybean quality in this study (as quantified by $\mathrm{CP}$ and RFV) was not affected by maturity group, with a maturity group VII variety harvested at R1 having similar quality to a maturity group $V$ variety harvested at $R 6$. The varieties of soybean used in this study demonstrated soil water extraction at a depth of $135 \mathrm{~cm}$ in most years. The average soil water extraction was $125 \mathrm{~mm}$. Using the forage soybean production function established in this study with long-term precipitation records and a soil water extraction of $125 \mathrm{~mm}$ produced a yield probability distribution indicating that there was a $90 \%$ chance of getting a break-even yield of $4256 \mathrm{~kg} \mathrm{ha}^{-1}$ at Akron, $\mathrm{CO}$, and that the average expected forage soybean yield at this location would be $5890 \mathrm{~kg} \mathrm{ha}^{-1}$. Regional estimates of soybean forage DM yields in the west-central Great Plains indicated mean yield ranging from 4770 to $6911 \mathrm{~kg} \mathrm{ha}^{-1}$. The results of this study support the use of forage soybean as an alternative forage crop for this region.

\section{Acknowledgement}

The author expresses his appreciation to Tawney Bleak for assistance with data analysis.

\section{References}

Analytical Software, 2008. Statistix 9 User's Manual. Analytical Software, Tallahassee, FL.

Cuniff, P., 1995. Official Methods Of Analysis of AOAC International, 16th ed. AOAC Int., Arlington, VA.

Darmosarkoro, W., Harbur, M.M., Buxton, D.R., Moore, K.J., Devine, T.E., Anderson, I.C., 2001. Growth, development, and yield of soybean lines developed for forage. Agron. J. 93, 1028-1034.

Devine, T.E., Hatley, E.O., 1998. Registration of 'Donegal' forage soybean. Crop Sci. 38, 1719-1720.

Devine, T.E., Hatley, E.O., Starner, D.E., 1998. Registration of 'Derry’ forage soybean. Crop Sci. 38, 1719-1720.

Devine, T.E., McMurtrey III, J.E., 2004. Registration of 'Tara' soybean. Crop Sci. 44 1020-1021

Fehr, W.R., Caviness, C.E., 1977. Stages of Soybean Development. Spec. Rep. 80. Iowa Agric. Home Econ. Exp. Stn., Iowa State Univ., Ames.

Heitholt, J.J., Kee, D., Farr, J.B., Read, J.C., Metz, S., MacKown, C.T., 2004. Forage from soybean provides an alternative to its poor grain yield in the southern Great Plains. Crop Manage., Available at www.plantmanagementnetwork.org/sub/ cm/research/2004/soybean/Heitholt.pdf, 06.04.05 (verified 09.02.11).

Hintz, R.W., Albrecht, K.A., Oplinger, E.S., 1992. Yield and quality of soybean forage as affected by cultivar and management practices. Agron. J. 84, 795-798.

Kuehn, C.S., Jung, H.G., Linn, J.G., Martin, N.P., 1999. Characteristics of alfalfa hay quality grades based on the relative feed value index. J. Prod. Agric. 123, 681-684.

MacKown, C.T., Heitholt, J.J., Rao, S.C., 2007. Agronomic feasibility of a continuous double crop of winter wheat and soybean forage in the southern Great Plains. Crop Sci. 47, 1652-1660.

Martin, D., 2007. Impact of advances in irrigation engineering and management. In: 2007 Water Law, Policy and Science Conference, The Future of Water Use in Agriculture, University of Nebraska, Lincoln, NE, March 26-27, 2007, Available at http://watercenter.unl.edu/WaterConference/2007WLPS/PPTs/Martin.pdf (verified 03.03.11).

Nielsen, D.C., 2004. Kenaf forage yield and quality under varying water availability. Agron. J. 96, 204-213.

Nielsen, D.C., Halvorson, A.D., Vigil, M.F., 2010a. Critical precipitation period for dryland maize production. Field Crops Res. 118, 259-263.

Nielsen, D.C., Peterson, G., Anderson, R., Ferriera, R., Shawcroft, W., Remington, K. 1996. Estimating corn yields from precipitation records. Conservation Tillage Facts \#2-96. Central Great Plains Research Station, Akron, CO.

Nielsen, D.C., Unger, P.W., Miller, P.R., 2005. Efficient water use in dryland cropping systems in the Great Plains. Agron. J. 97, 364-372.

Nielsen, D.C., Vigil, M.F., 2010. Precipitation storage efficiency during fallow in wheat-fallow systems. Agron. J. 102, 537-543.

Nielsen, D.C., Vigil, M.F., Benjamin, J.G., 2006. Forage yield response to water use for dryland corn, millet and triticale in the central Great Plains. Agron. J. 98 992-998.

Nielsen, D.C., Vigil, M.F., Benjamin, J.G., 2008. The variable response of dryland corn yield to soil water content at planting. Agric. Water Manage. 96, 330-336.

Nielsen, D.C., Vigil, M.F., Benjamin, J.G., 2010b. Evaluating decision rules for dryland rotation crop selection. Field Crops Res. 120, 254-261.

Poore, M., 2011. Interpreting forage analysis reports for beef cows. NC Cooperative Extension, Department of Animal Science. North Carolina State University, Raleigh, NC, Available at http://www.ncagr.gov/drought/documents/ InterpretingForageAnalysisReportsforBeefCows.pdf (verified 07.13.11).

Probst, A.H., Judd, R.w., 1973. Origin, U.S. history, development, and world distribution. In: Caldwell, B.E. (Ed.), Soybeans: Improvement, Production, and Uses, Agron. Monogr. 16. ASA, CSSA, and SSSA, Madison, WI, pp. 1-15.

Rao, S.C., Northup, B.K., 2008. Forage and grain sorghum effects on soil water content and use efficiency. Crop Sci. 48, 789-793.

Rao, S.C., Northup, B.K., 2009. Water use by five warm-season legumes in the southern Great Plains. Crop. Sci. 49, 2317-2324.

Seiter, S., Altemose, C.E., Davis, M.H., 2004. Forage soybean yield and quality responses to plant density and row distance. Agron. J. 96, 966-970.

Sheaffer, C.C., Orf, J.H., Devine, T.E., Jewett, J.G., 2001. Yield and quality of forage soybean. Agron. J. 93, 99-106.

Tanner, C.B., Sinclair, T.R., 1983. Efficient water use in crop production: research or re-search. In: Taylor, H.M., Jordan, W.R., Sinclair, T.R. (Eds.), Limitations to Efficient Water Use in Crop Production. ASA, CSSA, and SSSA, Madison, WI, pp. $1-27$.

Undersander, D., Mertens, D.R., Thiex, N., 1993. Determination of amylase neutral detergent fiber by refluxing (kettle method). In: Forage Analysis Procedures of the Natl. Forage Testing Assoc. Method 5.1. National Forage Testing Assoc., Omaha, NE.

Wiederholt, R., Albrecht, K., 2003. Using soybean as forage. Focus on Forage 5:1-2. Available online at www.uwex.edu/ces/crops/uwforage/SoybeanForageFOF.pdf (verified 02.03.11). 